\title{
ANALYSIS OF RICE SUPPLY CHAINS PERFORMANCE IN LARGE SCALE RICE REFINERIES IN BIREUEN REGENCY OF INDONESIA
}

\author{
Desparita Naya*, Kasimin Suyanti, Zakiah \\ Faculty of Agriculture, Syiah Kuala University, Indonesia \\ *E-mail: nayadesparita@gmail.com
}

\begin{abstract}
The importance of measuring the performance of the rice supply chain as a rice milling target is achieving success in its performance achievement. The rice supply chain starts from farmers, collectors, rice refiners, wholesalers, thinner traders and end consumers where every actor in the supply chain is interconnected with one another. The purpose of this study was to analyze and find out the level of performance of the rice supply chain in large scale rice refineries in Bireuen Regency. The method used to measure the performance of rice supply chains in large-scale rice refineries was the Supply Chain Operation Reference (SCOR). Performance measurement on the SCOR matrix in this study was assisted by the Analytical Hierarchy Process (AHP) and Snorm de boer methods. The results showed that there were 2 large scale rice refineries namely Sabar and Usaha Baru rice refineries in the average category and Al Barokah refineries in the marginal category. Overall, performance of large-scale rice refineries in Bireuen Regency was in the average category with a value of 53.95 means that the measurement of supply chain performance in large-scale rice refineries in Bireuen Regency is inefficient; to attain efficient supply chain performance in large-scale rice refineries, each refinery of large-scale rice must be in the category of good and excellent.
\end{abstract}

\section{KEY WORDS}

Supply chain performance, SCOR, AHP, efficient, supply chain, rice.

Supply Chain Management functions as an evaluation of suppliers of raw materials to a company with high quality raw material requirements, making it easier to distribute products according to end consumer standards and able to balance the threat of competitors of its kind (Gölgeci et al, 2019).

Lacks of grain supply, technology, capital support, conversion of agricultural land are common problems in rice mills that lead to unfair competition. (Majhi and Tushar, 2014) also suggested that several different conditions between small-scale rice mills, namely the level of sustainability was quite low. Adequate milling technology, high potential for growth, limited networks and financial resources are common problems faced with medium-scale rice mills. In large-scale mills most of the rice refineries have strong financial support, but the availability of large quantities of raw materials is still a problem, consequently having an impact on fulfilling unstable rice orders.

Types of rice mills can be categorized based on production capacity. Rice mills are divided into 3 groups, namely small scale rice mills (PPK) with production capacity $<5$ tons / day, medium scale rice mills (PPM) production capacity of 5-10 tons / day and large scale rice mills (PPB) capacity production of 10-27 tons / day (Suismono et al, 2013). Basic considerations in the selection of technology to be used in the milling such as technology prices, operational costs, and the cost of grinding the shipping process (Suryaninggrat and Fianeka, 2017). Among these 3 types of production scale, large scale production has tighter business competition than the other 2 production scales, in addition large scale demands high quality rice grain quality with the amount of production according to the target of rice refineries.

The performance of large-scale rice refineries is experiencing problems when the quality of grain obtained is low-quality grain, the percentage decrease in fulfillment of raw materials beyond the specified target can cause disruption of the performance of large-scale 
rice refineries. Large-scale rice refineries are able to compete with fellow large-scale rice refineries if the rice refineries are able to supply grain according to the targets set by the rice refineries. Measurement of the performance of the rice supply chain serves as a guideline for improvement for each member of the supply chain (Nurmahdy et al, 2020).

Large-scale rice refineries are unable to meet the supply of raw materials on target during the non-harvest season. This can cause uneven distribution of grain because the grain available in the non-harvest season is not sufficient to meet the needs of large-scale rice refineries (Putri, 2014).

In addition, large-scale rice refineries experience constraints when the process of returning from debt to cash as compensation for services received by rice refineries from the sale of rice experiences delays in payment so that it can hamper some activities due to lack of cash experienced by large-scale rice refineries.

The 3 large-scale rice refineries are found in Bireuen Regency, namely Sabar rice refineries, UD. Usaha Baru and AI Barokah are rice refineries which have been operating concurrently as distributors of rice for the Aceh region both locally and outside the region. The rice produced varies from $10 \mathrm{~kg}, 15 \mathrm{~kg}$ and $30 \mathrm{~kg}$ packaging depending on the order desired by the consumer. The research objective is to analyze and find out the level of performance of the rice supply chain in large scale rice refineries in Bireuen Regency.

\section{METHODS OF RESEARCH}

The research was carried out at a large scale rice refinery in Bireuen Regency with a research commodity, namely rice. Objects involved include farmers, collectors, rice refineries, large and small traders and end consumers. The scope of this study includes measuring performance at rice refineries in Bireuen Regency. The study was conducted in December 2019 to February 2020.

The sampling technique used non probability sampling, namely snowball sampling. Snowball sampling is a method that produces samples based on references made by people sharing or other people's presentations that present characteristics derived from research interests by identifying and interviewing directly using questionnaires to all members of the supply chain involved (Lopes et al, 1996). The sample consisted of farmers, collectors and workers or refinery owners in Bireuen District. The selection of 3 large-scale rice refineries was able to represent other rice refinery samples and was able to describe how the condition of the rice supply chain in the rice refineries in Bireuen District.

Table 1 - Research Sampling Framework on a Large Scale Rice Refinery in Bireuen District

\begin{tabular}{|c|c|c|c|}
\hline No & Location & Kind of Sample & Number of Quantity \\
\hline & & Sabar Rice Refineries & 2 \\
1. & Kutablang District & Farmers & 8 \\
& & Collector trader & 8 \\
& & Wholesalers & 8 \\
\hline & & Retailer & 8 \\
\hline & \multirow{3}{*}{ Juli District } & Usaha Baru Rice Refineries & 8 \\
& & Farmers & 8 \\
& & Collector trader & 8 \\
3. & Gandapura District & Wholesalers & 8 \\
& & Retailer & 2 \\
& & Al Barokah Rice Refineries & 8 \\
& & Farmers & 8 \\
\hline
\end{tabular}

Source: Primary Data (processed), 2020.

The primary data is obtained directly at the time of the study conducted obtained through observation and interviews with the help of questionnaires (Sugiono, 2016). Secondary data is data obtained from existing sources, consisting of literature, literature and information from previous studies that support research (Sugiono, 2016). The data needed in 
this study are primary and secondary data. Primary data were obtained from interviews using questionnaires with farmers, collectors, large traders, retailers and workers and owners of Rice Refineries in Bireuen Regency who will be respondents in this study. The total number of samples is 102 samples consisting of 3 locations namely Kutablang, Juli and Gandapura District. Each location has a large-scale rice refinery, farmers, collectors, large traders and retailers. Each member of the supply chain in 3 locations was sampled with 8 samples, while for the rice refinery only 2 people consisted of 1 owner of the rice factory and 1 worker representing other workers.

The Supply Chain Operation Reference (SCOR) provides a standard description of supply chain processes, performance metrics, best practices, and technology usage. Offering a comprehensive methodology for improving supply chain operations (Georgise et al, 2012). Supply Chain Operation Reference divides the process in the supply chain into 5 processes, namely: plan, namely the process of planning, source, namely the process of procuring raw materials, making a production process, deliver is a shipping process and return is a return process (Pujawan, 2010).

Table 2 - Performance Attributes and SCOR Metrics

\begin{tabular}{|c|c|c|c|}
\hline Process (Level 1) & Dimension (Level 2) & $\mathrm{KPI}$ & Key Performance Indicator (Level 3) \\
\hline \multirow{3}{*}{ Plan } & Reliability & P.R.1 & Customer meetings (Days) \\
\hline & Responsiveness & P.Re.1 & Production scheduling time interval (Days) \\
\hline & Asset & P.A.1 & Cash to cash cycle time (Days) \\
\hline \multirow{6}{*}{ Source } & \multirow{3}{*}{ Reliability } & S.R.1 & Raw material defects (\%) \\
\hline & & S.R.2 & Fulfillment of raw materials (tons) \\
\hline & & S.R.3 & On time delivery (Days) \\
\hline & Responsiveness & S.Re.1 & Raw Material Lead Time (Days) \\
\hline & Flexibility & S.F.1 & Lack of raw materials (tons) \\
\hline & Cost & S.C.1 & Order cost to supplier (Idr / ton) \\
\hline \multirow{6}{*}{ Make } & \multirow{2}{*}{ Reliability } & M.R.1 & Number of defective rice (tons) \\
\hline & & M.R.2 & Packing error (\%) \\
\hline & Responsiveness & M.Re.1 & Product manufacturing time (hours / day) \\
\hline & Flexibility & M.F.1 & Flexibility of raw materials in the production process (\%) \\
\hline & Cost & M.C.1 & Production costs (Idr / ton) \\
\hline & Asset & M.A.1 & $\begin{array}{l}\text { Average service life of the machine (oven, mill, sensor, digital } \\
\text { scale) (years) }\end{array}$ \\
\hline \multirow{2}{*}{ Deliver } & Reliability & D.R.1 & Fulfillment of products ready to send (tons / day) \\
\hline & Cost & D.C.1 & Goods shipping costs \\
\hline \multirow{2}{*}{ Return } & Reliability & R.R.1 & Customer complaint rate (ton) \\
\hline & Responsiveness & R.Re.1 & When replacing damaged products (tons) \\
\hline
\end{tabular}

Source: Supply Chain Council, 2006.

Analytical hierarchical process (AHP) method developed by Saaty. Other researchers use the AHP method for several selection processes to decide on an appropriate strategy (S. Luthra, 2016). The AHP method is applied to the selection process for the most appropriate scale of hydropower development for Nepal (Singh, 2016).

Determining priorities aims to find out the most important element in the problem, thus optimization can be done. Determination of priorities using a pairwise comparison matrix. Making a matrix with a comparison at each level, which level is more important based on the results of the assessment of several criteria in one level obtained from the optimization decision. Comparison between options for a hierarchical sub-system using the matrix $n \times n$, with $\mathrm{C}$ criteria and a number of $\mathrm{n}$ choices below Ai to An.

The criteria in one level obtained from the optimization decision. Comparison between options for a hierarchical sub-system using the matrix $n \times n$, with $C$ criteria and a number of $n$ choices below Ai to An.

In the $C$ criteria in the matrix table will be the top of the hierarchy by comparing $A 1, A 2$, $A 3, \ldots .$. An (row) with $A 1, A 2, A 3, \ldots .$. An (column) with the aim of seeing the level of relevance between $A 1, A 2, A 3, \ldots . . . A n$ (row) with $A 1, A 2, A 3, \ldots . . . A n$ (column) and so on is done until the matrix table is filled (Wardhani, 2014). 
Table 3 - Pairwise Comparison Matrix

\begin{tabular}{|c|c|c|c|c|}
\hline $\mathrm{C}$ & $\mathrm{A}_{1}$ & $\mathrm{~A}_{2}$ & $\mathrm{~A}_{3}$ & $\mathrm{~A}_{\mathrm{n}}$ \\
\hline $\mathrm{A}_{1}$ & $\mathrm{a}_{11}$ & $\mathrm{a}_{12}$ & $\mathrm{a}_{13}$ & $\mathrm{a}_{1 \mathrm{n}}$ \\
\hline $\mathrm{A}_{2}$ & $\mathrm{a}_{21}$ & $\mathrm{a}_{22}$ & $\mathrm{a}_{23}$ & $\mathrm{a}_{2 \mathrm{n}}$ \\
\hline $\mathrm{A}_{3}$ & $\mathrm{a}_{31}$ & $\mathrm{a}_{32}$ & $\mathrm{a}_{33}$ & $\mathrm{a}_{3 \mathrm{n}}$ \\
\hline $\mathrm{A}_{\mathrm{m}}$ & $\mathrm{a}_{\mathrm{m} 1}$ & $\mathrm{a}_{\mathrm{m} 2}$ & $\mathrm{a}_{\mathrm{m} 3}$ & $\mathrm{a}_{\mathrm{mn}}$ \\
\hline
\end{tabular}

Source: Saaty and Vargas, 2000.

A consistency test is carried out after the weighting process has been carried out in order to ensure an accurate and certain level of measurement. Measurement of consistency can be used the following formula:

$$
\mathrm{Cl}=\frac{(\lambda \max -\mathrm{n})}{(n-1)} \quad \text { (1) }(\text { Wardhani, 2014) }
$$

Based on the information above it can be concluded that the value of $\lambda$ max will not be smaller than the value of $n$ which causes the $\mathrm{Cl}$ will never be negative.

The formula of the Random Index is as follows:

$$
\mathrm{RI}=\frac{1.98(n-2)}{(n)}=\quad \text { (2) (Wibisono, 2006) }
$$

It was stated by Thomas, L 1993 that the determination of consistency ratio (CR) by using a comparison of $\mathrm{Cl}$ (consistency index) with $\mathrm{RI}$ (random index) which was formulated as follows:

$$
\mathrm{CR}=\frac{\mathrm{CI}}{\mathrm{RI}} \quad \text { (3) (Wibisono, 2006) }
$$

If the CR value is less than 0.100 or $10 \%$ then the inconsistency in making decisions can be accepted and vice versa if the CR is greater than 0.100 or $10 \%$ the chance of nonconformity in each level is not acceptable so it needs to be reviewed (Wibisono 2006).

Normalization is a technique or a way to manage data with the aim of eliminating and reducing data complexity so that it is easy to modify data. This was stated by Herlinda Padilah in 2017 that by eliminating the completeness of the data it can facilitate the normalization process because the data obtained from each indicator has different values and scales. The Snorm De Boer normalization formula is as follows:

$$
\text { Snorm }=\frac{(\text { Si }- \text { Smin })}{(\text { Smax }- \text { Smin })} \times 100 \quad \text { (4) }(\text { Sumiati, 2006) }
$$

Where: Si - The actual indicator value was successfully achieved; Smin - The worst performance achievement value of a performance indicator; Smax - The value of performance achievement is made up of performance indicators.

In this measurement each indicator weight is converted into a specific value interval of 0 to 100 . 0 means the worst and 100 is the best values, thus the indicator values are the same.

Table 4 - Performance Indicator Monitoring System

\begin{tabular}{|c|c|}
\hline Monitoring System & Performance Indicator \\
\hline$\leq 40$ & Poor \\
\hline $40-50$ & Marginal \\
\hline $50-70$ & Average \\
\hline $70-90$ & Good \\
\hline$\geq 90$ & Excellent \\
\hline
\end{tabular}

Source: Sumiati, 2006.

The designed hierarchical structure consists of general objectives at the first level namely the performance attributes of the SCOR model at the second level, level-1 strategic 
metrics, SCOR models at the third level, and finally the improvement plan at the final level (Abbaspour, 2019).

\section{RESULTS AND DISCUSSION}

Large-scale rice refineries generally play a role as rice producers in Bireuen District. There are 3 large scale permanent rice milling businesses from 10-27 tons / day, namely Sabar rice refinery, Usaha Baru rice refinery and Al Barokah rice refinery. These three rice refineries are in different sub-districts in Bireuen Regency. In addition to high production capacity, the application of technology and quality of rice produced by the three rice refineries has been recognized among the Bireuen community in general. These three rice refineries pass through several main activities, namely procurement of grain, grain milling, packaging and marketing of rice carried out by the rice refineries throughout the year and as much as the input owned by these three rice refineries.

Becker and N'guessan(2009) stated that in the rice supply chain there are four networks that must increase the role in the rice supply chain, namely farmers, rice refineries, traders, and workers who work at the rice supply chain institutions to be more active in the market aspect. Through this implementation a strategy is proposed, in order to obtain positive impacts resulting from the development of large-scale rice mill mills on other stakeholder farmers such as: increasing income and poverty of farmers, improving services to farmers, especially in milling processes, increasing the availability of jobs, especially in agro-industrial activities. In general, an improved strategy for the development of rice milling as part of agro-industry is still needed to improve the agriculture sector in Indonesia (Suryaninggrat and Fianeka, 2017).

At present in Indonesia, rice milling produces $80 \%$ into rice, $10-15 \%$ is broken rice and beer-making rice can be processed into flour and rice flour, while $10 \%$ rice bran is then processed into bran and its processed products. Modern rice mills have screener to separate head rice, broken rice, brewing rice and waste. On the other hand, manual screening will be carried out on small-scale rice mills. Thus it can produce high yields on milled rice heads, improve quality namely export quality and improve performance in the packaging and labeling process (Widowati and Luna, 2019).

The scale of business developed influences the presence of rice refineries in Bireuen Regency. Small and medium scale rice refineries are generally out of business in Bireuen Regency because the grain supplies obtained and capital are no greater than those of large scale rice refineries. On the other hand, large-scale rice refineries are able to compete, although there are several obstacles faced. This type of rice refinery is able to allocate grain in other regions as raw material stockpiles and is able to accommodate both private and banking capital. In addition, the applied innovation aspects can increase the income of largescale rice refineries even though the initial application is implemented which consumes large amounts of funds.

There are 19 Key Performance Indicators (KPI) in the three large-scale rice refineries namely Sabar, Usaha Baru and Al-Barokah that represent rice refineries in Bireuen Regency. The use of the same Key Performance Indicator (KPI) does not produce the same value; this is due to the different thinking and management in each rice refinery. Rice refineries in Bireuen Regency basically carry out simple management without looking at management aspects in more detail and specifics.

At level 1 the source has the highest weight reaching 0.45 or $45 \%$ and the plan has the lowest weight reaching 0.05 or only $5 \%$ while make with a weight of 0.27 or $27 \%$ and deliver with a weight of 0.16 or $16 \%$ while returns with a weight of 0.07 or $7 \%$. This shows that the main priority is the core source process followed by make, deliver, return and the last priority at this rice refineries' plan, the plan becomes the last priority because the resulting weight has the lowest value of only $5 \%$ at level 1 . Sabar rice Refinery prioritizes the fulfillment of raw materials because the rice refinery is a grain processing industry into rice, so the fulfillment of raw materials must be prioritized in order to achieve the target according to the needs of the rice refinery. 
Table 5 - Matrix of Supply Chain Performance Attributes and the Results of Sabar Rice Refineries Weighting

\begin{tabular}{|c|c|c|c|c|c|c|}
\hline $\begin{array}{l}\text { Process } \\
\text { (level 1) }\end{array}$ & Value & Dimension (level 2) & Value & $\mathrm{KPI}$ & Key Performance Indicator (Level 3) & Value \\
\hline \multirow{3}{*}{ Plan } & \multirow{3}{*}{0.05} & Reliability & 0.26 & P.r.1 & Customer meetings (Days) & 1.00 \\
\hline & & Responsiveness & 0.11 & P.Re.1 & Production scheduling time interval (Days) & 1.00 \\
\hline & & Asset & 0.63 & P.A.1 & Cash to cash cycle time (Days) & 1.00 \\
\hline \multirow{6}{*}{ Source } & \multirow{6}{*}{0.45} & \multirow{3}{*}{ Reliability } & \multirow{3}{*}{0.29} & S.r.1 & Raw material defects (\%) & 0.27 \\
\hline & & & & S.R.2 & Fulfillment of raw materials (tons) & 0.61 \\
\hline & & & & S.R.3 & On time delivery (Days) & 0.12 \\
\hline & & Responsiveness & 0.14 & S.Re.1 & Raw Material Lead Time (Days) & 1.00 \\
\hline & & Flexibility & 0.07 & S.F.1 & Lack of raw materials (tons) & 1.00 \\
\hline & & Cost & 0.5 & S.C.1 & Order cost to supplier (Idr / ton) & 1.00 \\
\hline \multirow{6}{*}{ Make } & \multirow{6}{*}{0.27} & \multirow{2}{*}{ Reliability } & \multirow{2}{*}{0.18} & M.r.1 & Number of defective rice (tons) & 0.88 \\
\hline & & & & M.R.2 & Packing error (\%) & 0.13 \\
\hline & & Responsiveness & 0.12 & M.Re.1 & Product manufacturing time (hours / day) & 1.00 \\
\hline & & Flexibility & 0.07 & M.F.1 & Flexibility of raw materials in the production process (\%) & 1.00 \\
\hline & & Cost & 0.37 & M.C.1 & Production costs (Idr / ton) & 1.00 \\
\hline & & Asset & 0.25 & M.A.1 & $\begin{array}{l}\text { Average service life of the machine (oven, mill, sensor, } \\
\text { digital scale) (years) }\end{array}$ & 1.00 \\
\hline \multirow[t]{2}{*}{ Deliver } & \multirow{2}{*}{0.16} & Reliability & 0.22 & D.r.1 & Fulfillment of products ready to send (Tons / Day) & 1.00 \\
\hline & & Cost & 0.62 & D.C.1 & Goods shipping costs & 1.00 \\
\hline \multirow{2}{*}{ Return } & \multirow{2}{*}{0.07} & Reliability & 0.66 & R.r.1 & Customer complaint rate (Ton) & 1.00 \\
\hline & & Responsiveness & 0.33 & R.Re.1 & When replacing damaged products (Ton) & 1.00 \\
\hline
\end{tabular}

Source: Primary Data (processed), 2020.

Table 6 - Matrix of Supply Chain Performance Attributes and the Results of Usaha Baru Rice Refineries Weighting

\begin{tabular}{|c|c|c|c|c|c|c|}
\hline $\begin{array}{l}\text { Process } \\
\text { (level 1) }\end{array}$ & Value & Dimension (level 2) & Value & $\mathrm{KPI}$ & Key Performance Indicator (Level 3) & Value \\
\hline \multirow{3}{*}{ Plan } & \multirow{3}{*}{0.05} & Reliability & 0.23 & P.r.1 & Customer meetings (Days) & 1.00 \\
\hline & & Responsiveness & 0.08 & P.Re.1 & Production scheduling time interval (Days) & 1.00 \\
\hline & & Asset & 0.69 & P.A.1 & Cash to cash cycle time (Days) & 1.00 \\
\hline \multirow{6}{*}{ Source } & \multirow{6}{*}{0.51} & \multirow{3}{*}{ Reliability } & \multirow{3}{*}{0.24} & S.r.1 & Raw material defects (\%) & 0.21 \\
\hline & & & & S.R.2 & Fulfillment of raw materials (tons) & 0.70 \\
\hline & & & & S.R.3 & On time delivery (Days) & 0.09 \\
\hline & & Responsiveness & 0.20 & S.Re.1 & Raw Material Lead Time (Days) & 1.00 \\
\hline & & Flexibility & 0.07 & S.F.1 & Lack of raw materials (tons) & 1.00 \\
\hline & & Cost & 0.49 & S.C.1 & Order cost to supplier (Idr / ton) & 1.00 \\
\hline \multirow{6}{*}{ Make } & \multirow{6}{*}{0.23} & \multirow{2}{*}{ Reliability } & \multirow{2}{*}{0.16} & M.r.1 & Number of defective rice (tons) & 0.83 \\
\hline & & & & M.R.2 & Packing error (\%) & 0.17 \\
\hline & & Responsiveness & 0.13 & M.Re.1 & Product manufacturing time (hours / day) & 1.00 \\
\hline & & Flexibility & 0.08 & M.F.1 & Flexibility of raw materials in the production process (\%) & 1.00 \\
\hline & & Cost & 0.38 & M.C.1 & Production costs (Idr / ton) & 1.00 \\
\hline & & Asset & 0.25 & M.A.1 & $\begin{array}{l}\text { Average service life of the machine (oven, mill, sensor, } \\
\text { digital scale) (years) }\end{array}$ & 1.00 \\
\hline \multirow{2}{*}{ Deliver } & \multirow{2}{*}{0.12} & Reliability & 0.25 & D.r.1 & Fulfillment of products ready to send (Tons / Day) & 1.00 \\
\hline & & Cost & 0.75 & D.C.1 & Goods shipping costs & 1.00 \\
\hline \multirow{2}{*}{ Return } & \multirow{2}{*}{0.08} & Reliability & 0.83 & R.r.1 & Customer complaint rate (Ton) & 1.00 \\
\hline & & Responsiveness & 0.16 & R.Re.1 & When replacing damaged products (Ton) & 1.00 \\
\hline
\end{tabular}

Source: Primary Data (processed), 2020.

The core plan process has the lowest weight that is 0.05 or only $5 \%$ while other core processes have a higher weight, namely the source reaches 0.51 or $51 \%$, make 0.23 or $23 \%$, deliver 0,12 or $12 \%$ and return 0.08 or $8 \%$. Plan is level 1 with the lowest weight. This shows that the plan will be the last priority in the Usaha Baru rice refinery and the source will be the main priority in the Usaha Baru rice refinery because this rice refinery depends on fulfilling the raw materials that must be completed according to the desired target of the refinery rice.

The source weight is the highest weight reaching 0.46 or $46 \%$ and the plan with the lowest weight is 0.05 or only $5 \%$ while the make is at weight 0.26 or $26 \%$ and deliver 0.16 or $16 \%$ while return with a weight of 0.07 or $7 \%$. This shows that the rice mill prioritizes source as the first priority in the core level 1 process followed by make, deliver and return and finally 
plan. This means that the Al Barokah rice refinery at level 1 plan becomes the last priority of the Large Scale Refinery Scoring System in Bireuen Regency.

The calculation of normalization values by equalizing parameters to performance indicators, the results can be compared performance (Rica, 2016). Following is the calculation of KPI normalization value based on the actual, best and worst conditions achieved by the three rice refineries sampled in Bireuen District.

Raw material defect KPI, packing error, punctual delivery time, product manufacturing time and average machine usage have a normalization value with a score of $100 \%$, while other KPIs below the score of 100 range between $34.49-66.67 \%$. This shows that KPIs that have a normalized value of 100 are KPIs that are in good condition.

Table 7 - Matrix of Supply Chain Performance Attributes and the Results of Al Barokah Rice Refineries Weighting

\begin{tabular}{|c|c|c|c|c|c|c|}
\hline $\begin{array}{l}\text { Process } \\
\text { (level 1) }\end{array}$ & Value & Dimension (level 2) & Value & $\mathrm{KPI}$ & Key Performance Indicator (Level 3) & Value \\
\hline \multirow{3}{*}{ Plan } & \multirow{3}{*}{0.05} & Reliability & 0.27 & P.r.1 & Customer meetings (Days) & 1.00 \\
\hline & & Responsiveness & 0.12 & P.Re.1 & Production scheduling time interval (Days) & 1.00 \\
\hline & & Asset & 0.61 & P.A.1 & Cash to cash cycle time (Days) & 1.00 \\
\hline \multirow{6}{*}{ Source } & \multirow{6}{*}{0.46} & \multirow{3}{*}{ Reliability } & \multirow{3}{*}{0.32} & S.r.1 & Raw material defects (\%) & 0.18 \\
\hline & & & & S.R.2 & Fulfillment of raw materials (tons) & 0.70 \\
\hline & & & & S.R.3 & On time delivery (Days) & 0.11 \\
\hline & & Responsiveness & 0.15 & S.Re.1 & Raw Material Lead Time (Days) & 1.00 \\
\hline & & Flexibility & 0.12 & S.F.1 & Lack of raw materials (tons) & 1.00 \\
\hline & & Cost & 0.41 & S.C.1 & Order cost to supplier (Idr / ton) & 1.00 \\
\hline \multirow{6}{*}{ Make } & \multirow{6}{*}{0.26} & \multirow{2}{*}{ Reliability } & \multirow{2}{*}{0.20} & M.r.1 & Number of defective rice (tons) & 0.83 \\
\hline & & & & M.R.2 & Packing error (\%) & 0.17 \\
\hline & & Responsiveness & 0.11 & M.Re.1 & Product manufacturing time (hours / day) & 1.00 \\
\hline & & Flexibility & 0.09 & M.F.1 & Flexibility of raw materials in the production process (\%) & 1.00 \\
\hline & & Cost & 0.33 & M.C.1 & Production costs (Idr / ton) & 1.00 \\
\hline & & Asset & 0.27 & M.A.1 & $\begin{array}{l}\text { Average service life of the machine (oven, mill, sensor, digital } \\
\text { scale) (years) }\end{array}$ & 1.00 \\
\hline \multirow{2}{*}{ Deliver } & \multirow{2}{*}{0.16} & Reliability & 0.25 & D.r.1 & Fulfillment of products ready to send (Tons / Day) & 1.00 \\
\hline & & Cost & 0.75 & D.C.1 & Goods shipping costs & 1.00 \\
\hline \multirow{2}{*}{ Return } & \multirow{2}{*}{0.07} & Reliability & 0.75 & R.r.1 & Customer complaint rate (Ton) & 1.00 \\
\hline & & Responsiveness & 0.25 & R.Re.1 & When replacing damaged products (Ton) & 1.00 \\
\hline
\end{tabular}

Source: Primary Data (processed), 2020.

It is explained that the flexibility of raw material KPI gets the lowest normalization value of $38.09 \%$ and the highest is on the KPI on time delivery, packing error and the average machine usage reaches a score of $100 \%$, whereas other KPIs obtained normalization scores below $100 \%$.

In KPI, the order cost for a supplier gets the lowest score, which is only $10 \%$ compared to other cost scores, such as production costs with a score of $48.74 \%$ and shipping costs with a normalized score of $70,37 \%$ better than the cost of orders to supplier. This explains that the cost of orders to suppliers has the lowest level of normalization. The calculation of the final value on each dimension contained in level 2 , the calculation is obtained by multiplying the final value of the KPI by the weight of each dimension.

The classification of monitoring systems in each core process that occurs in the Sabar Rice Refinery is in the average classification ranges from a score of $51.03-69.42$. This explains that overall improvements need to be made considering that each core process has not yet reached the monitoring system in the good and excellent category.

The final value of dimensions in each core process, namely plan, make, deliver and return with values ranging from 54.67 - 67.82 , belongs to the average monitoring system while sources based on classification with a value of 47.71 are included in the marginal category. This rice refinery has to improve the core source process first because this core process in the rice refinery is the most important core process to remember the source or raw material is the main thing to pay attention to compared to the core process plan, make, deliver and return. The core process that is in the average monitoring system must be able to change and make improvements in order to be in the good or excellent category.

The final dimension in each process of the core plan, make and deliver is classified as average with a value of $61.20,64.71$ and 57.12 while source is in a marginal position with a 
value of 32.37, while the return is in a good position with a value of 72.92 . This explains that the main improvements that must be corrected in the core process are source and subsequent delivery, plan and make and finally returns so that they are able to be in a good and excellent position.

Table 11 - Calculation of Final Value Dimensions of Sabar Rice Refineries

\begin{tabular}{|c|c|c|c|c|c|c|}
\hline $\begin{array}{l}\text { Process } \\
\text { (Level 1) }\end{array}$ & $\begin{array}{c}\text { Dimension } \\
\text { (Level 2) }\end{array}$ & $\begin{array}{c}\text { Total Dimension } \\
\text { Score }\end{array}$ & Value & $\begin{array}{c}\text { Final Score (Score } x \\
\text { Value) }\end{array}$ & $\begin{array}{c}\text { Total of } \\
\text { Processes } \\
\end{array}$ & System Monitoring \\
\hline \multirow{3}{*}{ Plan } & Reliability & 52.93 & 0.26 & 13.76 & \multirow{3}{*}{59.54} & \multirow{3}{*}{ Average } \\
\hline & Responsiveness & 55.56 & 0.11 & 6.11 & & \\
\hline & Asset & 62.96 & 0.63 & 39.66 & & \\
\hline \multirow{4}{*}{ Source } & Reliability & 64.36 & 0.29 & 18.66 & \multirow{4}{*}{51.03} & \multirow{4}{*}{ Average } \\
\hline & Responsiveness & 56.25 & 0.14 & 7.88 & & \\
\hline & Flexibility & 52.29 & 0.07 & 3.66 & & \\
\hline & Cost & 41.67 & 0.5 & 20.84 & & \\
\hline \multirow{5}{*}{ Make } & Reliability & 54.91 & 0.18 & 9.88 & \multirow{5}{*}{69.42} & \multirow{5}{*}{ Average } \\
\hline & Responsiveness & 100 & 0.12 & 12 & & \\
\hline & Flexibility & 34.99 & 0.07 & 2.45 & & \\
\hline & Cost & 54.28 & 0.37 & 18.43 & & \\
\hline & Asset & 100 & 0.25 & 25 & & \\
\hline \multirow{2}{*}{ Deliver } & Reliability & 50 & 0.2 & 10 & \multirow{2}{*}{56.65} & \multirow{2}{*}{ Average } \\
\hline & Cost & 58.31 & 0.8 & 46.65 & & \\
\hline \multirow{2}{*}{ Return } & Reliability & 66.67 & 0.66 & 44 & \multirow{2}{*}{66.00} & \multirow{2}{*}{ Average } \\
\hline & Responsiveness & 66.67 & 0.33 & 22 & & \\
\hline
\end{tabular}

Source: Primary Data (processed), 2020.

Table 12 - Calculation of Final Value Dimensions of Usaha Baru Rice Refineries

\begin{tabular}{|c|c|c|c|c|c|c|}
\hline $\begin{array}{l}\text { Process } \\
\text { (Level 1) }\end{array}$ & Dimension (Level 2) & $\begin{array}{l}\text { Total Dimension } \\
\text { Score }\end{array}$ & Value & $\begin{array}{c}\text { Final Score (Score } \mathrm{x} \\
\text { Value) }\end{array}$ & $\begin{array}{c}\text { Total of } \\
\text { Processes }\end{array}$ & System Monitoring \\
\hline \multirow{3}{*}{ Plan } & Reliability & 45.79 & 0.23 & 10.53 & \multirow{3}{*}{59.32} & \multirow{3}{*}{ Average } \\
\hline & Responsiveness & 66.8 & 0.08 & 5.34 & & \\
\hline & Asset & 62.96 & 0.69 & 43.44 & & \\
\hline \multirow{4}{*}{ Source } & Reliability & 57.44 & 0.24 & 13.79 & \multirow{4}{*}{47.11} & \multirow{4}{*}{ Marginal } \\
\hline & Responsiveness & 53.4 & 0.20 & 10.68 & & \\
\hline & Flexibility & 46.36 & 0.07 & 3.25 & & \\
\hline & Cost & 39.58 & 0.49 & 19.39 & & \\
\hline \multirow{5}{*}{ Make } & Reliability & 63.11 & 0.16 & 10.10 & \multirow{5}{*}{67.82} & \multirow{5}{*}{ Average } \\
\hline & Responsiveness & 75 & 0.13 & 9.75 & & \\
\hline & Flexibility & 38.09 & 0.08 & 3.05 & & \\
\hline & Cost & 52.43 & 0.38 & 19.92 & & \\
\hline & Asset & 100 & 0.25 & 25.00 & & \\
\hline \multirow[t]{2}{*}{ Deliver } & Reliability & 49.03 & 0.25 & 12.26 & \multirow[t]{2}{*}{54.67} & \multirow{2}{*}{ Average } \\
\hline & Cost & 56.55 & 0.75 & 42.41 & & \\
\hline \multirow[t]{2}{*}{ Return } & Reliability & 66.67 & 0.83 & 55.34 & \multirow[t]{2}{*}{66.76} & \multirow{2}{*}{ Average } \\
\hline & Responsiveness & 71.43 & 0.16 & 11.43 & & \\
\hline
\end{tabular}

Source: Primary Data (processed), 2020.

Table 13 - Calculation of Final Dimensions of Al Barokah Rice Plant Dimensions

\begin{tabular}{|c|c|c|c|c|c|c|}
\hline $\begin{array}{l}\text { Process } \\
\text { (Level 1) }\end{array}$ & Dimension (Level 2) & $\begin{array}{l}\text { Total Dimension } \\
\text { Score }\end{array}$ & Value & $\begin{array}{c}\text { Final Score (Score } x \\
\text { Value) }\end{array}$ & $\begin{array}{c}\text { Total of } \\
\text { Processes }\end{array}$ & System Monitoring \\
\hline \multirow{3}{*}{ Plan } & Reliability & 57.39 & 0.27 & 15.50 & \multirow{3}{*}{61.20} & \multirow{3}{*}{ Average } \\
\hline & Responsiveness & 44.83 & 0.12 & 5.38 & & \\
\hline & Asset & 66.11 & 0.61 & 40.33 & & \\
\hline \multirow{4}{*}{ Source } & Reliability & 51.58 & 0.32 & 16.51 & \multirow{4}{*}{32.37} & \multirow{4}{*}{ Marginal } \\
\hline & Responsiveness & 41.75 & 0.15 & 6.26 & & \\
\hline & Flexibility & 45.86 & 0.12 & 5.50 & & \\
\hline & Cost & 10.00 & 0.41 & 4.10 & & \\
\hline \multirow{5}{*}{ Make } & Reliability & 52.35 & 0.20 & 10.47 & \multirow{5}{*}{64.71} & \multirow{5}{*}{ Average } \\
\hline & Responsiveness & 75.00 & 0.11 & 8.25 & & \\
\hline & Flexibility & 32.29 & 0.09 & 2.91 & & \\
\hline & Cost & 48.74 & 0.33 & 16.08 & & \\
\hline & Asset & 100.00 & 0.27 & 27 & & \\
\hline \multirow{2}{*}{ Deliver } & Reliability & 17.35 & 0.25 & 4.34 & \multirow{2}{*}{57.12} & \multirow{2}{*}{ Average } \\
\hline & Cost & 70.37 & 0.75 & 52.78 & & \\
\hline \multirow{2}{*}{ Return } & Reliability & 75.00 & 0.75 & 56.25 & \multirow[t]{2}{*}{72.92} & \multirow{2}{*}{ Good } \\
\hline & Responsiveness & 66.67 & 0.25 & 16.67 & & \\
\hline
\end{tabular}

Source: Primary Data (processed), 2020.

Determination of the monitoring system aims to determine the last performance indicators whether the indicators are in poor, marginal, average, good and excellent (Sumiati, 2006). 
Table 14 - Monitoring System of Rice Refinery Supply Chain Performance in Bireuen Regency

\begin{tabular}{|c|c|}
\hline Rice Refineries & Final Score \\
\hline Sabar & 58.37 \\
\hline Usaha Baru & 54.49 \\
\hline Al Barokah & 49,01 \\
\hline Jumlah & 161,87 \\
\hline Rata-rata & 53,95 \\
\hline
\end{tabular}

Source: Primary Data (processed), 2020.

Sabar and Usaha Baru rice refineries are at an average level with values of 58.37 and 54.49 while the performance of the Al Barokah rice refinery has a value of 49.01 including in the marginal position this shows that the performance system of the refined rice supply chain rice in Bireuen Regency does not yet have a rice mill with supply chain performance that is in the good and excellent category.

Sabar rice refineries are the most efficient large-scale rice refineries compared to two other rice refineries when viewed from the monitoring results that have been measured using Analiytical Hierarchy Processes and Supply Chain Operation Reference because they have the highest final value of 58.37, although they are still classified in the average category. Overall performance of the rice refinery supply chain in Bireuen Regency is in the category 53.95 which is included in the average position. Rice refineries in Bireuen Regency still need to be done to improve overall performance and core processes to achieve good and excellent levels.

\section{CONCLUSION}

The results of measuring the performance of rice supply chains in large-scale rice refineries in Bireuen Regency are inefficient as seen from the low performance of large-scale rice refineries in key performance indicators flexibility of availability of raw materials that affect the core source process causes large-scale rice refineries are unable to meet the raw material targets in accordance with which has been determined by each of the large-scale rice refineries. Sabar and Usaha Baru rice refineries are in an average position while Al Barokah refineries are in a marginal position, among 3 large scale rice refineries, Sabar rice refineries are the most efficient when viewed based on the final performance value of 58.37 but overall rice supply chain performance still in the average position with a value of 53.95 so that to obtain the performance of rice supply chains in efficient large-scale rice refineries each large-scale rice refinery must be in the good and excellent category.

\section{REFERENCES}

1. Abbaspour, A. 2019.Supply Chain Analysis and Improvement by Using the SCOR Model and Fuzzy AHP: A Case Study. International Journal of Industrial Engineering \& Management Science. 6 (2): 51-73.

2. Aulia. M. 2017. Analisis Konsumsi Beras. Tesis. Program Studi Magister Ilmu Ekonomi. Universitas Syiah Kuala. Banda Aceh.

3. Athaillah, T., Ahmad, H.H and Indra. 2018. Analisis Rantai Pasok (Supply Chain) Ikan Tuna pada CV Tuah Bahari and PT Nagata Prima Tuna di Banda Aceh. Marine Fisheries. 9 (2): 169-181.

4. Becker. L. N'guessan. Y. 2009. Rice Producer-Processor Networks in CÔte d'ivoire. International Journal of Geographical Review. 99(2): 164-185.

5. Chiadamrong, N. \& Piyathanavong, V. 2017. Optimal Design of Supply Chain Network Under Uncertainty Environment Using Hybrid Analytical and Simulation Modeling Approach. Journal of Industrial Engineering International. 13(4): 465-478.

6. Gölgeci, I., Karakas, F., \& Tatoglu, E. (2019). Understanding Demand and Supply Paradoxes and Their Role in Business-to-Business Firms. Industrial Marketing Management. 79: 169-180. 
7. Georgise, F.B., Thoben, K.B. and Seifert, M. 2012. Adapting the Scor Model to Suit the Different Scenarios: A Literature Review \& Research Agenda. International Journal of Business and Management. 7(6): 2-17.

8. Luthra. S. Sachin. K. M. Lei. X. Ali. D. 2016. Using Ahp to Evaluate Barriers in Adopting Sustainable Consumption and Production Initiatives in a Supply Chain. International Journal of Production Economics. 181-342.

9. Lopes, C.S., 1996. The Lack of Selection Bias in a Snowball Sampled Case-Control Study on Drug Abuse. International Journal of Epidemiology. 25(6): 1267-1269.

10. Majhi. B. K. and Tushar. J. 2014. Studies on Performance of the Cogeneration Programme in Rice Mills in West Bengal. 4th International Conference on Advances in Energy Research 2013, ICAER 2013. Energy Procedia. 54: 105-110

11. Nurchalis. 2015. Manajemen Rantai Pasok Komoditas Kelapa Sawit di Pantai Barat Aceh. Tesis Magister Agribisnis. Universitas Syiah Kuala. Banda Aceh.

12. Nurmahdy. A. I. Machfud. \& M. Faiz. S. 2020. Kinerja Rantai Pasok Beras di Kabupaten Karawang. Jurnal Aplikasi Manajemen and Bisnis. 6 ( 2).

13. Pujawan, I N. (2010). Supply Chain Management. Guna Widya. Surabaya.

14. Padillah. H. Yulison. H. C. Agung. W. 2016. Model Supply Chain Operation Reference (SCOR) and Analytic Hierarchy Process (AHP) untuk Sistem Pengukuran Kinerja Supply Chain Management. Prosiding Seminar Nasional Sains Teknologi ke-7 Tahun 2016. Fakultas Teknik Universitas Wahid Hasyim Semarang. 1(1): 31-36.

15. Rica. Y. S. 2016. Pengukuran Kinerja Supply Chain Dengan Pendekatan Scor di Baristand Industri Surabaya. Jurnal Teknologi Proses and Inovasi Industri. 2 (1): 65-71.

16. Saaty, T. L., \& Vargas, L. G. (2000). Model, Method, Concepts \& Applications of the Analytical Hierarcy Process.New York: Springer Science Business Media.

17. Singh. R. P. and Hans. P. N. 2016. Analytical Hierarchy Process (AHP) Application for Reinforcement of Hydropower Strategy in Nepal. Renewable and Sustainable Energy Reviews. 55(1): 43-58.

18. Sutopo,W. Ayu, E. Arien, H. 2016. Optimizing Supply Chain Based on Agreement Buyer - Supplier Relationshipwith Network Design Problem. Makara J. Technol. 20 (3) 114-120

19. Subroto. A. M. Lotje. K. Jacky. S. 2015. Evaluasi Kinerja Supply Chain Manajemen pada Produksi Beras di Desa Panasen Kecamatan Kakas. Jurnal Emba. 3 (1): 653-662.

20. Sugiyono. (2016). Metode Penelitian Kuantitatif Kualitataif and Kombinasi (Mixedmethods). Bandung: Alfabeta.

21. Suismono. Rachmat. R. Sumantri. A. \& Tjahjohutomo. R. 2013. Kajian model agroindustri padi berbasis klaster. Artikel Pangan. 22(2): 1-17.

22. Sumiati, 2006. Pengukuran Performansi Supply Chain Perusahaan Dengan Pendekatan Supply Chain Operation Reference (SCOR) di PT Madura Guano Industri. Fakultas Teknologi Industri. UPN Veteran Jawa Timur.

23. Suryaninggrat. I.B. and Fianeka.A. 2017. Developing Strategy for Rice Milling Unit Selection Process Using Analytical Hierarchy Process (ahp) method: a case of agroindustry in Indonesia. Adv. Sci. Lett. 23(12): 11787-11792.

24. Wardhani, Y. K. 2014. Model Optimasi and Manajemen Risiko Pada Saluran Distribusi Rantai Pasok Sayuran Dataran Tinggi di Kabupaten Sumatera Utara and Sumatera Barat. Tesis. IPB Bogor.

25. Wibisono, D. 2006. Manajemen Kinerja: Konsep Desain and Teknik meningkatkan Daya Saing Perusahaan. Jakarta: Erlangga.

26. Widowati. S. and P. Luna. 2019. Food Processing Technology: Case Study on the Development of Rice Bioindustry. IOP Conf. Series: Earth and Environmental Science. doi:10.1088/1755-1315/309/1/012028. 